\title{
THE MULTI-AGENCY RESPONSE APPROACH TO THE MANAGEMENT OF OIL SPILL INCIDENTS: LEGAL FRAMEWORK FOR EFFECTIVE IMPLEMENTATION IN NIGERIA
}

\author{
Ayobami Olaniyan*
}

\begin{abstract}
he devastating effects of oil spill incidents on humans and the

1 environment can be overwhelming. Effects such as loss of life, forced displacements, loss of property and serious health risks cannot be overlooked. Also, the long-term damage to the ecosystem, sea life and biodiversity are some of the long-term consequences of an oil spill incident. Thus, a swift response to oil spill incidents is always necessary in order to minimize these effects. The multi-agency response approach emphasizes a holistic and coordinated involvement of several related institutions and entities in order to ensure adequate response to any category of oil spill incident. Even though the multi-agency approach seems to be already embedded in relevant legislation on oil spill control and containment in Nigeria, its operationalization has been less impressive. This article discusses the practical relevance and implementation of multiagency response to oil spills in Nigeria. It appraises the efficacy of relevant Nigerian legislation providing for multi-agency response to oil spill control and containment in Nigeria, highlights the weaknesses of the current regulatory arrangement, and suggests legal reforms to make the multi-agency response approach more efficient and effective in Nigeria. This includes the need to harmonize several overlapping legislations and governance institutions on oil spill response and management to ensure coherence and systemic integration.
\end{abstract}

Keywords: Multi Agency Response, oil spill, polluter-pays, human rights, Niger Delta.

doi: http://dx.doi.org/10.4314/jsdlp.v6i1.5

* LL.B (Ife), B.L (Abuja), LL.M (Aberdeen), Lecturer, College of Law, Afe Babalola University, Ado-Ekiti (ABUAD), Nigeria; ajolaniyan@abuad.edu.ng, ayobamiolaniyan@gmail.com; Associate Fellow at the Institute for Oil, Gas, Energy, Environment and Sustainable Development, Afe Babalola University, Nigeria. 


\section{INTRODUCTION}

$\mathrm{O}$ spill incidents are common occurrences in Nigeria, especially in the Niger Delta area. Prominent oil spill incidents include the Bonga (2011); ${ }^{1}$ GOCON's Escarvous (1978); Idoho (1998); Shell Petroleum Development Company (SPDC)'s Forcados Terminal (1978); and Texaco Funiwa 5-Blowout (1980). ${ }^{2}$ The Niger Delta area, which harbours a substantial proportion of Nigeria's oil and gas deposits ${ }^{3}$ is plagued with so many problems that make incidents of oil spill rampant. Vandals, militants, saboteurs, oil companies and the government have all contributed in one way or the other to this situation in the Niger Delta. To protect lives, properties, the environment, and business investments, drastic actions have to be taken to curb incessant oil spills.

The multi-agency approach is about different ministries, services, agencies, professionals and other relevant stakeholders across the oil sector working together to ensure speedy, adequate and effective responses to oil spills. According to the United Nations, establishing a multi-agency approach framework involves identifying key contacts and agency representatives; establishing personal links between the various agency contacts; developing multi-agency training; jointly assessing the local priorities and developing strategies and action plans; sharing intelligence and data; developing protocols for working jointly and agreeing on management structures and the processes for developing the multi-agency approach further. ${ }^{4}$ A good example where the multi-agency approach was used successfully is the United States during the Deepwater Horizon oil spill of 2010; an on-scene coordinator (OSC) from the U.S. Coast Guard directed and coordinated on-site activities of federal, state, local, and private entities (such as BP and its contractors) against the oil spill. ${ }^{5}$

1 Adedayo Ojo, “Bonga, Endeavour \& Macondo" < http://africaoilgasreport.com/ 2012/05/opinion/bonga-endeavour-macondo/> accessed 5 May 2015.

2 Peter C. Nwilo and Olusegun T. Badejo, "Impacts and Management of Oil Spill Pollution Along the Nigerian Coastal Areas" <www.fig.net/pub/figpub/pub36/ chapters/chapter_8.pdf $>$ accessed 3 December 2014.

3 Damilola S. Olawuyi, The Principles of Nigerian Environmental Law: Essential Readings (Business Perspectives 2013) 144.

4 United Nations, "Developing a multi-agency approach to intervention" <www.unodc.org/documents/human-trafficking/Toolkit-files/08-58296_tool_212.pdf $>$ accessed 27 February 2015.

5 Jonathan L. Ramseur and Curry L. Hagerty, “Deepwater Horizon Oil Spill: Recent Activities and Ongoing Developments” (CRS Report for Congress, 31 January 2013) <www.fas.org/sgp/crs/misc/R42942.pdf> accessed 3 January 2015. 
Multi-agency also simply means “... several different organizations that work together for a shared aim...”. ${ }^{6}$ In this context, multi-agency refers to those organizations that work together to respond to oil spill incidents in Nigeria. There are many advantages of this approach. They include the following:

(1) Better information/intelligence sharing: agencies involved in the multi-agency response would share information freely and better when they know that all agencies involved are working towards a common goal, which in this case is to prevent or stop oil spill incidents.

(2) Improved decision making: an efficient multi-agency approach help agencies involved to make coherent decisions to prevent oil spills.

(3) Enhanced coordinated and timely intervention: when multiple agencies work together on a particular project and each one performs its roles to the letter, there would be coordinated response and timely intervention to deal with the spill at hand.

(4) Improved response: responses to oil spill incidents are faster. Oil spill incidents are not left for a long period of time before they are attended to after a report has been made. These are some of the advantages that make the multi-agency approach attractive and better than a one-way response approach.

Oil spills have negative effects on the environment. The ability to deal with oil spill incidents over time requires immediate response and effective coordination of all agencies and parties to avoid devastating damage to the environment. A single spill can cause unimaginable harm to the surrounding communities and even further afield than the immediate spill site; hence, the need for a rapid and coordinated response action. There are several stakeholders involved for any single spill incident, all of which have roles and responsibilities with respect to the response plan. Such stakeholders include the government, oil companies, oil industry associations and residents of the affected community. It is therefore imperative to have a well-organized and effective multi-agency response in order to avert huge losses. A well-coordinated response among the relevant agencies is crucial to a successful oil spill response.

6 Macmillan Dictionary, "Multi-Agency" <www.macmillandictionary.com/ dictionary/british/multi-agency> accessed 14 February 2015. 
Furthermore, institutional harmony and coordination among key agencies and ministries are also crucial to any discussion on the multiagency oil spill response model. Institutions such as the Federal Ministry of Environment and State Ministries of Environment (especially in the Niger Delta region) are important in this discussion. Agencies here include the National Oil Spill Detection and Response Agency (NOSDRA), National Oil Pollution Management Agency (NOPMA), ${ }^{7}$ National Emergency Management Agency (NEMA), Department of Petroleum Resources (DPR), and the Nigerian Maritime Administration and Safety Agency (NIMASA). Other critical stakeholders including oil companies and the Clean Nigeria Associates (a not-for-profit second-tier oil spill response cooperative organization $)^{8}$ also play a major role in response to oil spill incidents in Nigeria. To a large extent, relevant legislations, regulations and guidelines have been put in place to strengthen multiagency response to oil spills in Nigeria. However, their practical implementation has not produced effective results. Several of these laws contain conflicting and overlapping provisions that often result in incoherence and fragmentation.

This article appraises legislation (and guidelines), which include the National Oil Spill Detection and Response Agency (establishment) (NOSDRA) Act No.15 2006; the National Oil Spill Detection and Response Agency (amendment) Bill 2012; the National Emergency Management (establishment, Etc.) Act Cap N34 LFN 2004; and the Environmental Guidelines and Standards for the Petroleum Industry in Nigeria (EGASPIN) 2002, to examine how they aid or hinder multiagency response to oil spills in Nigeria. Furthermore, the article examines the legal framework for achieving further institutional leveraging, harmony and coherence in Nigeria with a view to promoting multi-agency approach to oil spill response.

The ultimate aim of the article is to discuss possible solutions to make the multi-agency response approach efficient and effective. It discusses the key normative strengths of this approach which include: better information/intelligence sharing among oil spill response agencies; improved decision making; enhanced coordinated and timely intervention

7 This Agency is yet to be established. It is to be created by the National Oil Spill Detection and Response Agency (Amendment) Bill 2012 which is yet to be passed into law. See Policy and Legal Advocacy Center (PLAC), "Senate Bills Chart", <www.placng.org/new/senate-bills-charts.php?page=9> accessed 6 May 2015. 
and improved response by relevant oil spill response agencies. This article proposes practical legal reform approaches through which the multiagency response approach could be better recognized in Nigerian laws. The article specifically argues for: a comprehensive single guideline on multi-agency oil spill response; resolving areas of conflict in the responsibilities of NOSDRA and DPR; improved security of oil installations and security in the country; and commitment of the government to deal with oil spill incidents in Nigeria.

This article is divided into six sections. After this introduction, section 2 examines the current state of multi-agency response to oil spill incidents in Nigeria. Section 3 reviews the laws providing for multi-agency response in Nigeria. Section 4 discusses the different challenges facing the multiagency response approach in Nigeria. Section 5 makes recommendations for improving multi-agency response in Nigeria. The article concludes in Section 6.

\section{CURRENT STATE OF MULTI-AGENCY RESPONSE TO OIL SPILL INCIDENTS IN NIGERIA}

There are numerous provisions in existing laws in Nigeria that provide for the multi-agency response model. These laws are scattered in several sources and often establish parallel and competing institutions. As such, the effective operationalization of the multi-agency response concept is absent. The challenges inhibiting the implementation of a successful multiagency response regime include scattered and competing legislation, incoherent spill detection requirements and tiered response mechanisms across diverse agencies, inappropriately transplanted best practices, and the lack of institutional coordination amongst key agencies and ministries. These problems frustrate the implementation of a multi-agency approach to oil spill detection and clean up in Nigeria. This does not suggest that the concept is inapplicable but the practical operationalization of the concept as a model of response to oil spill incidents is being seriously called to question.

Response to an oil spill ought to start immediately the spill is detected or reported. ${ }^{9}$

9 This is in line with the provision of the Nigerian Environmental Guidelines and Standards for the Petroleum Industry in Nigeria (EGASPIN) which provides in paragraph 2.6.3, "Containment Procedures and Clean-up of oil spills" that cleanup of an oil spill must commence within 24 hours of the occurrence of the spill. 
In Nigeria, response to an oil spill is based on the tiered response system. ${ }^{10}$ This system ensures that spills are responded to according to their category and involves an investigation of the incident by a joint investigation team. ${ }^{11}$ This team investigates the cause of the oil spill, jointly agrees and signs a report that confirms the cause of the spill and it also includes other key information such as the volume of oil spilt and the area affected. ${ }^{12}$

The agency at the forefront of response to oil spill incidents is the National Oil Spill Detection and Response Agency (NOSDRA). NOSDRA is the federal agency with the statutory responsibility for preparedness, detection and response to all oil spillages in Nigeria. ${ }^{13}$ However, in many cases, it is observed that oil companies' personnel usually lead oil spill investigations and NOSDRA does not initiate oil spill investigations. ${ }^{14}$ The agency is thus seen to be dependent on the company involved in an oil spill incident, whether it involves conveying NOSDRA staff to oil spill sites or supplying technical data about spills. ${ }^{15}$ Furthermore, the process of joint investigation is heavily reliant on the oil companies. ${ }^{16}$ The oil companies often decide when the investigation will take place, they usually provide transport to the site and they provide technical expertise, which the regulatory agencies such as NOSDRA and the DPR do not have. ${ }^{17}$

The problem with this arrangement immediately becomes apparent where the polluter (or party responsible for the operation of the polluted site) wields so much influence, takes leadership and controls the flow of information. A poorly equipped government agency, as NOSDRA is

10 This categorization is spelt out in section 9.0 of the National Oil Spill Contingency Plan (NOSCP) for Nigeria, May, 2009. Tier 1: Operational type spills (less than or equal to 7 tonnes [50bbls]); Tier 2: a large spill (greater than 7 tonnes [50bbls] but less than 700 tonnes [5000bbls]; Tier 3: the large spill (greater than 700 tonnes [5000bbls]).

11 See EGASPIN 2002 "Spill Prevention and Counter Measures Plan", Paragraph 5.1.1.1.

12 Amnesty International, "Bad Information: Oil Spill Investigations in the Niger Delta" (2013) <www.amnesty.org> accessed 25 November 2014.

13 National Oil Spill Detection and Response Agency (Establishment) Act 2006, section 1 (1).

14 Amnesty International (n 13).

15 ibid.

16 ibid.

17 ibid. 
however, has little or no choice but to make the best of such a situation. ${ }^{18}$ In the next section, a brief review of relevant legislation and regulations, which provide for the operation of the multi-agency response model to oil spill incidents is undertaken.

\section{LEGAL FRAMEWORK FOR MULTI-AGENCY RESPONSE TO OIL SPILL INCIDENTS IN NIGERIA}

\subsection{The National Oil Spill Detection and Response Agency (Establishment) Act No.15, 2006}

This is the principal legislation on the response to oil spill incidents in Nigeria. It established the National Oil Spill Detection and Response Agency (NOSDRA). ${ }^{19}$ NOSDRA is statutorily empowered to coordinate and control response to oil spills in the country. The objectives, functions and special functions of the agency are enumerated in section 5, 6 and 7, respectively, of the agency's establishing Act (the National Oil Spill Detection and Response Agency (Establishment) Act No.15, 2006). The agency is saddled with the responsibility of coordinating and implementing the National Oil Spill Contingency Plan for Nigeria.

The objectives of NOSDRA as regards spill response are provided for specifically in sections 5 (c)-(k) of the Act, and point to its primacy in oil spill response. Two of these objectives are relevant to the discussion on the existence and leadership of the multi-agency response to oil spill incidents in Nigeria. First, to "establish the mechanism to monitor and assist or where expedient direct the response, including the capability to mobilize the necessary resources to save lives, protect threatened environment, and clean up to the best practical extent of the impacted site" ${ }^{20}$ Secondly, to "maximize the effective use of the available facilities and resources of corporate bodies, their international connections and oil spill co-operatives, that is Clean Nigeria Associates (CNA) in

18 For example, Amnesty International (n 13) reports that oil spill investigations are organized and led by oil companies and not NOSDRA. An example of this situation was given of a NOSDRA director (Rivers State) that was notified by text message by an oil company of a joint investigation visit to an oil spill incident. Amnesty International reports that NOSDRA is told when a joint investigation visit will be done either by text message or a letter.

19 See NOSDRA Act, section 1 (1).

20 ibid section 5 (c). 
implementing appropriate spill response". ${ }^{21}$

From the first provision above, the aim of establishing NOSDRA is to have an agency that has the ability to organize and direct response activities and also to have an agency that has the ability to mobilize resources which may include resources from other institutions or even other countries. From the second provision above, NOSDRA will be an agency that will manage different agencies'organizations' resources in order to ensure an appropriate response to oil spills. These two provisions envisage that NOSDRA will imbibe the multi-agency response concept. However, these provisions do not explicitly put NOSDRA as lead agency, as it is only subtly referenced in (i).

The function of NOSDRA is clearly spelt out in sections 6 and 7 of the NOSDRA's Act. From its name, and the various interpretations of the two sections above, it can be inferred that NOSDRA's main responsibility is the detection of oil spills and coordination of response to oil spills in the country. However, as regards its leadership role in a multi-agency response to oil spill incidents, section 7 (g)(ii) of NOSDRA's establishing Act provides that:

The Director-General shall have the power to co-opt all the Government, Ministries and Agencies mentioned under the Second Schedule to this Act, in the management of a Tier 3 or a major Tier 2 oil spill..$^{22}$

The above section empowers NOSDRA to utilize the multi-agency approach to oil spill incidents in Nigeria. The provision gives the directorgeneral of NOSDRA the power to coordinate a multi-agency response of governments, ministries, and agencies listed in the second schedule of the Act to manage a tier 3 or a major tier 2 oil spill. The governments, ministries, and agencies referred to here are the Nigerian Institute of Oceanography and Marine Research, Federal Ministry of Works, Federal Ministry of Health, Federal Ministry of Transport, Federal Ministry of Information, Federal Ministry of Water Resources, Federal Ministry of Agriculture and Rural Development, Ministry of Communications, Federal Ministry of Aviation (NIMET), Ministry of Science and Technology, Ministry of Defence, the Nigerian Police Force as well as

21 ibid section $5(\mathrm{~d})$.

22 ibid. 
the National Emergency Management Agency. Others include Oil Producers Trade Section/Lagos Chamber of Commerce (OPTS); NonGovernmental Organizations, Industrial Groups and Academic Organizations. The duties of each of these agencies during a tier 2 or tier 3 spill are also provided for under the second schedule to the Act. It is instructive to note here that section 7 (g) (ii) does not make multi-agency response applicable to a tier 1 oil spill incident.

Other important sections to note here are sections 18 and 19 of the Act. Section 18 provides for the establishment of the National Control and Response Centre. This centre is the "report processing and response coordinating centre for all oil spillage incidents in Nigeria". ${ }^{23}$ It is also empowered to 'serve as the command and control centre for compliance monitoring of all existing legislation on environmental control, surveillance for oil spill detection and monitoring and coordinating responses required in plan activations. ${ }^{24}$ Section 19 further emphasizes the multi-agency concept and NOSDRA's leadership. It provides that NOSDRA shall act as the lead agency on all matters relating to oil spill response management and shall work with other agencies when it comes to major or disastrous oil spills as spelt out in Schedule 2 of the Act. ${ }^{25}$ In that section, NOSDRA is made the lead agency on matters relating to oil spills response management. ${ }^{26}$ NOSDRA is also expected to liaise with other agencies on the implementation of the plan contained in the second schedule. $^{27}$

From the forgoing, it is clear that the NOSDRA Act makes copious provisions for multi-agency response to oil spill incidents in Nigeria however; it is noteworthy that challenges such as lack of the necessary manpower, requisite technology and inadequate funding inhibit the performance of NOSDRA and the practical implementation of the multiagency response model in the country. For example, Amnesty International reports that oil spill investigations are usually led by oil company personnel, not NOSDRA and that NOSDRA is usually notified

23 ibid section 18 (a).

24 ibid section 18 (c)

25 ibid section 19 (1). The 2 nd schedule directs that NOSDRA work with other agencies during Tier 2 and Tier 3 oil spill incidents. The 2 nd schedule also provides for the roles of each agency NOSDRA is to work with.

26 section 19 (2).

27 Ibid. 
by text message or letter when an oil spill investigation will take place. ${ }^{28}$ Ordinarily, the reverse should be the case, since NOSDRA is the regulatory agency saddled with the responsibility to deal with oil spills; it should take the lead in oil spill investigations.

\subsection{The National Oil Spill Detection and Response Agency (Amendment) Bill 2012}

Though not yet in force, the National Oil Spill Detection and Response Agency (amendment) Bill 2012 (NOSDRA Amendment Bill) seeks to amend the National Oil Spill Detection and Response Agency (establishment) Act No.15, 2006. It is still at the stage of Second Reading before the Nigerian Senate. ${ }^{29}$ Under this Bill, NOSDRA will become National Oil Pollution Management Agency (NOPMA). ${ }^{30}$ NOPMA will take on the responsibilities of NOSDRA with additional functions. ${ }^{31}$ NOPMA is saddled with the "responsibility to prevent, detect, minimize and respond to all oil spillages and pollution as well as gas flaring and leakages and other hazardous and obnoxious substances in the petroleum sector..." 32

NOSDRA Amendment Bill puts NOPMA in charge of the coordination of response activities throughout Nigeria of oil spill and gas leakages. ${ }^{33}$ Thus, NOPMA will eventually be the agency responsible for multi-agency response to oil spill incidents in Nigeria when the Bill is passed into law. Also, this Bill intends to add the Federal Fire Service, Nigerian Customs and the Immigration Service to the list of multi-agency response organizations provided for in the second schedule of the National Oil Spill Detection and Response Agency (establishment) Act No.15, 2006 that will respond to an oil spill incident in Nigeria. ${ }^{34}$

28 Amnesty International (n 13).

29 Lynda Dunkwu, "A Review of the National Oil Spill Detection and Response Agency (Amendment) Bill 2012: Identifying Loopholes for Improvements" <www.academia.edu/8732244/A_Review_of_the_Nigerian_Oil_Spill_ Detection_And_Response_Agency_Amendment_Bill> accessed 4 February 2015.

30 NOSDRA Amendment Bill 2012, section 1 (2).

31 ibid section 6 .

32 ibid section 1 (2).

33 ibid section 6 (c).

34 The Federal Fire Service is expected to deal with fire resulting from an oil spill while the Nigerian Customs ensures easy access and egress of oil spill equipment out of Nigeria and the Immigration Service ensures that experts can come in and out of Nigeria. 


\subsection{The National Oil Spill Contingency Plan (NOSCP) ${ }^{35}$}

The NOSCP is a policy document for "cost-effective response mechanism for oil spills within the territories of the Federal Republic of Nigeria" ${ }^{36}$ This document details the Nigerian contingency response plan towards oil spill incidents in the country. The NOSCP spells out the role of the government as regards its responsibility towards protecting the Nigerian environment from oil spillages (accidental or deliberate) of any size and from any source, which threaten the Nigerian environment. ${ }^{37}$

As regards multi-agency response to oil spills in the country, the NOSCP aims to: "establish the mechanism to either monitor and assist or if necessary to direct the actual response, including the capability to swiftly mobilize the necessary resources to save lives, protect threatened environment, and clean up to the best practical extent of the polluted site" ${ }^{38}$ Secondly, it aims to "maximize the effective use of the available facilities and resources of individual companies, their international connections and oil spill cooperatives in implementing appropriate spill response". ${ }^{39}$ The above provisions show that the NOSCP aims to have a multi-agency response to oil spill incidents in Nigeria.

Furthermore, paragraph 7.1 of the NOSCP specifically highlights key government ministries and agencies which have important roles to play in the event of a major oil spill. ${ }^{40}$ The roles of these organizations and bodies are contained in paragraph 8.0 of NOSCP. Here again, NOSCP makes the National Oil Spill Detection and Response Agency (NOSDRA) the lead agency on all matters relating to oil spill response management. ${ }^{41}$ NOSDRA is also expected to liaise with the Federal Ministry of Petroleum Resources for the implementation of NOSCP. ${ }^{42}$ NOSCP also mandates the National Emergency Management Agency (NEMA) to work alongside NOSDRA in coordinating oil spill emergencies. ${ }^{43}$

35 Revised Edition, May 2009.

36 National Oil Spill Contingency Plan (NOSCP), Paragraph 1.1.

37 NOSCP, Paragraph 2.1.

38 NOSCP, Paragraph 6.1.1.3.

39 NOSCP, Paragraph 6.1.1.4.

4025 main groups. the ministries and agencies mentioned here include: The Federal Ministry of Environment; Ministry of Defence; Ministry of Petroleum Affairs; Nigerian Police and the National Emergency Management Agency (NEMA).

41 NOSCP, Paragraph 8.2.

42 ibid.

43 NOSCP, Paragraph 8.19. 


\subsection{National Emergency Management (Establishment, Etc.) Act}

\section{Cap N34 L.F.N. 2004}

The National Emergency Management (Establishment, Etc.) Act Cap N34 LFN 2004 (NEMA Act) establishes the National Emergency Management Agency (NEMA).$^{44}$ NEMA is responsible for formulating policies on activities relating to disaster management and coordinating plans and programmes on response to disasters (natural and otherwise) in Nigeria. ${ }^{45}$ According to the NEMA Act, oil spillage is among the disasters NEMA can respond to. ${ }^{46}$ Thus, NEMA can, by virtue of its enabling law, participate in multi-agency response effort to an oil spill in Nigeria. The NEMA Act does not specify the category of oil spill that NEMA can participate in, but it provides that NEMA is in charge of educating and informing the public on disaster prevention and control measures, ${ }^{47}$ coordinating and facilitating provision of resources for search and rescue and other types of disaster curtailment activities; ${ }^{48}$ distributing emergency relief materials to victims of natural disasters ${ }^{49}$; liaising with international bodies for the reduction of natural and other disasters ${ }^{50}$ among other important functions of the agency.

Notably, a major challenge hindering the efficiency of NEMA is inadequate funding. For instance, NEMA has not been able to implement disaster risk reducing ${ }^{51}$ strategies in many areas as it should because of this challenge. ${ }^{52}$

44 NEMA Act 2004, Section 1 (1).

45 ibid section 6 (1) (a).

46 ibid section 6 (2).

47 ibid section 6 (1) (e).

48 ibid section 6 (1) (f).

49 ibid section $6(1)(\mathrm{j})$.

50 ibid section $6(1)(\mathrm{m})$.

51 The United Nations Office for Disaster Risk Reduction <www.unisdr.org/whowe-are/what-is-drr> accessed 1 April 2015, says “Disaster Risk Reduction” involves activities which involves "reducing exposure to hazards, lessening vulnerability of people and property, wise management of land and the environment, and improving preparedness and early warning for adverse events...”.

52 Abdul-Akeem Sadiq, "A Look at Nigeria’s Bourgeoning Emergency Management System: Challenges, Opportunities, and Recommendations for Improvement" <http://training.fema.gov/hiedu/aemrc/booksdownload/compemmgmtbook project/> accessed 30 March 2015. 


\subsection{Nigerian Maritime Administration and Safety Agency Act No. 17, 2007}

Nigerian Maritime Administration and Safety Agency Act, 2007 (NIMASA Act) establishes the Nigerian Maritime Administration and Safety Agency (NIMASA). ${ }^{53}$ One key aim of NIMASA is to "regulate and promote maritime safety and maritime labour", ${ }^{54}$ and "control and prevent marine pollution". ${ }^{55}$ The Act makes the agency one of the federal agencies that can participate in multi-agency response to oil spill incidents in Nigeria especially in the prevention and control of marine pollution. However, the NIMASA Act does not elaborate on how the agency will control and prevent marine pollution. One effective way of combating marine pollution is collaboration with relevant agencies. Collaboration can be in the form of data and information sharing, especially at it relates to oil pollution. Lack of effective collaboration with agencies such as NOSDRA and NEMA can be a challenge to NIMASA. NIMASA needs to collaborate with other agencies to be able to prevent marine pollution caused by an oil spill.

\subsection{Environmental Guidelines and Standards for the Petroleum Industry in Nigeria (EGASPIN) ${ }^{56}$}

This guideline was issued by the Department of Petroleum Resources (DPR) as a result of rising concern for adverse environmental impacts arising from oil-related pollution. ${ }^{57}$ EGASPIN aims to establish guidelines and standards for environmental quality control of the petroleum industry in Nigeria ${ }^{58}$ and to achieve the standardization of environmental pollution abatement and monitoring procedures in the Nigerian oil and gas industry. ${ }^{59}$ EGASPIN also seeks to provide a comprehensive document on pollution abatement technology, guidelines and standards for the

\footnotetext{
53 NIMASA Act 2007, section 3 (1).

54 ibid section 1 (1) (i).

55 ibid section 22 (1) (i).

56 Revised Edition, 2002.

57 EGASPIN 2002, paragraph 3, part 1, Introduction.

58 ibid paragraph 4 (a), part 1 , Introduction.

59 ibid para 4 (c), part 1 , Introduction.

60 ibid para 4 (b), part 1, Introduction.
} 
Nigerian petroleum industry. ${ }^{60}$

Moreover, EGASPIN provides that all crude oil/chemical/oil products spillages shall be reported to the Director of Petroleum Resources (Department of Petroleum Resources) according to the Oil Spillage/ Notification Reporting Formats. ${ }^{61}$ Thus, all oil spillage incidents are expected to be reported to the DPR. The above provision also puts the DPR at the forefront of response to oil spills and allows it to coordinate response to oil spills in the country. In relation to multi-agency response, EGASPIN provides that within 24 hours of oil spill notification to the DPR, a "Joint Spillage Investigation" (JSI) team, which comprises the Licensee/Operator/Spiller, Community and the DPR shall be constituted. ${ }^{62}$ This provision does not specifically provide that the DPR will lead the JSI team but as the sole government agency in this team and the agency which receives notification of any oil spill, the DPR is in the lead as regards response efforts towards oil spill incidents.

Furthermore, EGASPIN provides that an "Oil Spill Contingency Plan" (an organized and predetermined course of action to be pursued in the event of a spill) shall be compiled in a document by all operators in the petroleum industry for the approval of the Director of Petroleum Resources. ${ }^{63}$ This provision of the EGASPIN, gives the DPR the authority to approve all Oil Spill Contingency Plans of all operators in the petroleum industry. Thus, the DPR has a crucial role to play in terms of dictating the type of response given to oil spill incidents in the country.

\section{LEGAL BARRIERS AND CHALLENGES TO EFFECTIVE IMPLEMENTATION OF A MULTI- AGENCY RESPONSE APPROACH IN NIGERIA}

As noted above, multi-agency response to oil spill incidents in Nigeria is hindered by a number of practical problems that reduce legislative coherence and institutional harmony. This section of the article will

61 ibid para 5.1.1, "Spill Prevention and Counter Measures Plan".

62 ibid para 5.1.1.1, "Spill Prevention and Counter Measures Plan".

63 ibid para 1.0, part B, "Contingency Planning for the Prevention, Control and Combating of Oil and Hazardous Substances Spills”. 
synthesize and discuss these problems.

\subsection{Conflicts in Responsibilities between the National Oil Spill Detection and Response Agency (NOSDRA) and the Department of Petroleum Resources (DPR)}

The first challenge identified here is the apparent conflict between NOSDRA and DPR. NOSDRA is the statutory institution saddled with the responsibility of coordinating response to oil spill incidents in the country. From the provisions of the National Oil Spill Detection and Response Agency (Establishment) Act No.15, 2006 (NOSDRA Establishment Act), ${ }^{64}$ this important responsibility is laid out. The Act also provides that NOSDRA is in charge of the coordination and implementation of the Plan (the National Oil Spill Contingency Plan) for Nigeria. ${ }^{65}$ From these provisions, it is expressly clear that NOSDRA is the agency in charge of oil spill response. However, the Environmental Guidelines and Standards for the Petroleum Industry in Nigeria (EGASPIN) provides that all oil spillage incidents shall be reported to the Director of Petroleum Resources. ${ }^{66}$ The foregoing provision of EGASPIN, therefore, conflicts with section 6 (1) (b) of the NOSDRA Establishment Act. These conflicting provisions make room for "double reporting", which amounts to a waste of time and defeats the essence of an efficient multi-agency response to oil spill incidents, which is to provide quick and effective response. Conflicting provision such as this should not be in laws governing the industry.

\subsection{Inadequate Resources by the National Oil Spill Detection and Response Agency (NOSDRA) and the Department of Petroleum Resources (DPR)}

The National Oil Spill Detection and Response Agency (NOSDRA) and the Department of Petroleum Resources (DPR) are the two major agencies involved in multi-agency response to oil spill incidents in Nigeria. Lack of adequate funding, requisite technology and trained manpower are the recurrent problems faced by NOSDRA and the DPR. These government agencies are involved in the joint team that investigates the cause(s) of an

64 NOSDRA Establishment Act, section 6 (1) (b).

65 ibid section 6 (1) (c) and Section 7 (a).

66 EGASPIN 2002, Para 5.1.1, "Spill Prevention and Counter Measures Plan".

67 Amnesty International (n 13). 
oil spill. ${ }^{67}$ This joint investigation process can be seen as one way of responding to an oil spill. The joint spillage investigation team is to be constituted within 24 hours of spillage notification. ${ }^{68}$ Environmental Guidelines and Standards for the Petroleum Industry in Nigeria (EGASPIN) says:

The Joint investigation team investigates the cause of the oil spill and it is expected to jointly agree and sign a report that confirms the cause of the spill, and other key information such as the volume of oil spilt as well as the area affected. ${ }^{69}$

It is however noted that the process of joint investigation is heavily reliant on the oil companies by essentially placing the burden of reporting on the companies. ${ }^{70}$ The oil companies decide when the investigation will take place; they usually provide transport to the site and they provide technical expertise, which the regulatory agencies, such as NOSDRA and the DPR, do not have. ${ }^{71}$ To this extent, the "spill detection" responsibility of NOSDRA is largely absent or, at best, weak.

\subsection{Inadequate Enforcement of Environmental Laws and Guidelines}

From the analysis of the relevant laws above, it is evident that provisions relating to multi-agency response to oil spill abound. However, there is always the problem of strict enforcement of laws due to one inadequacy or the other on the part of the relevant agency or the government as a whole. Thus, provisions of the National Oil Spill Detection and Response Agency (Establishment) Act No.15 2006 and the National Oil Spill Contingency Plan (NOSCP) regarding multi-agency response may not be strictly adhered to. The benefits of well-coordinated multi-agency response to oil spills in the country cannot be realized without strict enforcement and implementation of existing environmental laws and guidelines relating to multi-agency response to oil spills by relevant

68 Environmental Guidelines and Standards for the Petroleum Industry in Nigeria (EGASPIN), 2002, Paragraph 5.1.1.1.

69 Amnesty International (n 13).

70 ibid.

71 ibid.

72 Support agencies here encompass the agencies involved in multi-agency oil spill response. 
support agencies. ${ }^{72}$

\subsection{Insecurity}

Insecurity is a major issue in Nigeria and the Niger Delta, especially as regards multi-agency response to oil spills. Insecurity is caused mainly by an upsurge in the activities of militants and terrorists. Nowadays, the state of insecurity in the Niger Delta is such that anyone can be kidnapped. ${ }^{73}$ Insecurity in the Niger Delta is observed to "... always emerge as a result of resistance campaigns through the kidnapping of expatriates and demonstrating the inability of Nigerian Security Forces to stop attacks, as well as the sabotage of oil installations and the effective use of the global news media". ${ }^{74}$ The result of this state of insecurity is that no one is entirely safe in the Niger Delta. Thus, those saddled with the responsibility of responding to oil spills can be kidnapped, leaving the oil spill unattended to or sabotaging investigations into the immediate cause(s) of the spill for days/weeks or months until those held hostage are freed. Moreover, oil spill cases are not attended to immediately as required by EGASPIN. It may take days or even weeks for a particular oil spill to be attended to as opposed to the 24-hour requirement by EGASPIN. ${ }^{75}$ Securing the pipelines and other oil and gas assets in Nigeria is a heavy burden on the government because it makes Nigeria to lose about 120,000 to 150,000 barrels of oil to smugglers every day. ${ }^{76}$

\subsection{Incessant Pipeline Vandalism and Oil Theft}

This is another major challenge hindering the multi-agency response model in Nigeria. Pipeline vandalism and oil theft are common occurrences in the Niger Delta region. In 2010, the Nigerian National Petroleum Corporation (NNPC) reported about 5000 cases of vandalism

73 P. Oromareghake, R Arisi, M Igho, "Youth Restiveness and Insecurity in Niger Delta: A Focus on Delta State” (2013) 13 Global Journal of Human Social Science Political Science <http://socialscienceresearch.org/index.php/GJHSS/article/ view/594/541> accessed 5 December 2014.

74 ibid.

75 (EGASPIN) 2002 (Environmental Guidelines and Standards for the Petroleum Industry in Nigeria) para 2.6.3, "Containment Procedures and Clean-Up of Spills".

76 P. Oromareghake (n 73).

77 David Alabi, “Militancy, Amnesty and Peace in Nigeria's Niger Delta" <http:// motresource.com/wp-content/uploads/2014/01/Militancy-Amnesty-and-Peacein-the-Niger-Delta.-2.pdf $>$ accessed 24 November 2014. 
in the Niger Delta as opposed to about seven cases reported in $1993 .{ }^{77} \mathrm{It}$ is also reported that Nigeria loses about US\$3.65 million annually to oil theft. $^{78}$ The above statistics on both oil theft and pipeline vandalism show the enormity of these acts. Oil thieves are always at work siphoning crude oil from oil pipelines and selling it illegally on the international market. ${ }^{79}$ Pipeline vandalism and oil theft make multi-agency response difficult and complex because these acts occur regularly and vandals revisit remediated oil spill sites and destroy them again, leading to further oil spills. Such spills may eventually result in pipeline explosions and even the death of perpetrators of these acts. ${ }^{80}$ Moreover, the collaboration between state security agents responsible for security of oil installations, the government and oil multinational personnel contribute to oil theft in Nigeria. ${ }^{81}$ These groups help facilitate oil theft and enrich themselves at the detriment of the state, thus encouraging large-scale illegal oil bunkering at oil export terminals. ${ }^{82}$

\section{ENHANCING THE MULTI-AGENCY APPROACH TO OIL SPILL MANAGEMENT IN NIGERIA: RECOMMENDATIONS ON THE WAY FORWARD}

Given the necessity of dealing with any oil spills because of the attendant consequences and the numerous benefits of dealing with an oil spill through an effective multi-agency response, drastic solutions are imperative in order to have a successful multi-agency response to oil spill incidents in Nigeria.

First, areas of conflict between NOSDRA Establishment Act and EGASPIN should be harmonized so that NOSDRA, and not the DPR, is fully and legally empowered to be responsible for leadership of the

78 Goddey Wilson, “The Nigerian State and Oil Theft in the Niger Delta Region of Nigeria" (2014) 16 Journal of Sustainable Development in Africa <www.jsdafrica.com/Jsda/Vol16No1-Spring2014A/PDF/The\%20Nigerian\%20State \%20and\%20Oil\%20Theft.pdf $>$ accessed 1 September 2014.

79 P. Nwilo and O. Badejo, "Impacts and Management of Oil Spill Pollution along the Nigerian Coastal Areas" <www.fig.net/pub/figpub/pub36/chapters/ chapter_8.pdf $>$ accessed 3 December 2014.

80 ibid. Here, it was reported that in July 2000, a pipeline explosion occurred outside the city of Warri, Delta State where 250 people died. Also, it was reported that an explosion in Lagos State in December 2000 killed 60 people.

81 Goddey Wilson (n 78).

82 ibid. 
multi-agency response to oil spills in the country. This will ensure that the multi-agency response model is not just provided for in Nigerian laws but is efficient and seen to be so. Responsibilities of NOSDRA should not be duplicated under provisions stipulating the responsibilities of the DPR as evidenced in the NOSDRA Establishment Act and EGASPIN ${ }^{83}$ Also, existing provisions relating to multi-agency response scattered in different legislations should be harmonized. Specifically, provisions in the NOSDRA Act 2006, NOSDRA Bill 2012, NEMA Act 2004, NIMASA Act and EGASPIN 2002 should be harmonized to give a coherent whole. This will ensure that there is no duplication of duties of oil spill response agencies in different laws in Nigeria.

Second, the relevant laws relating to multi-agency response to oil spill in the country should be strictly implemented and enforced by NOSDRA and relevant support agencies. Where there is inadequate enforcement and implementation of laws by relevant agencies, the laws will remain dormant while relevant agencies needed for an effective multiagency response process remain uncoordinated. Coordination of relevant response agencies is important for the success of the multi-agency response approach. Implementation and enforcement is also necessary for timely, swift and efficient response of relevant agencies. Good response mechanisms put in place to deal with oil spills will help reduce their impact on the Nigerian environment.

Third, a workable single comprehensive operational guideline on multi-agency response to oil spills should be drawn up by NOSDRA and implemented by it and all relevant support agencies in the multiagency process in order to ensure success of the multi-agency response model. Specific details of the multi-agency response strategy/plan should be contained in this guideline. This guideline would also specify details of the roles and responsibilities of each supporting agency and, most importantly, the agency responsible for coordinating multi-agency response to oil spill in the country. It is also suggested that provisions relating to multi-agency response which are contained in various laws and guidelines discussed in Section 3 above can be reviewed and consolidated into this operational guideline. It is important to note that this guideline must be reviewed periodically to accommodate new developments in the Nigerian oil industry.

Fourth, the Nigerian government must be sincere and committed to

83 See the NOSDRA Establishment Act 2006, section 6 (1) (b) of and EGASPIN 2002, Paragraph 5.1.1, "Spill Prevention and Counter Measures Plan”. 
dealing with oil spill by strengthening and making NOSDRA more autonomous so that it can independently undertake its responsibilities and duties as provided by its enabling Act. Adequate funding, technology and manpower are required for this to be successful. Moreover, relevant agencies are to be adequately funded for a successful multi-agency response approach. ${ }^{84}$

Lastly, governments at all levels must tackle the problem of insecurity by dealing decisively with corruption, militancy, vandalism and oil theft using existing legislation. If insecurity is not urgently tackled, it will be difficult to respond adequately to an oil spill because responders themselves will not be safe. Adequate resources must be provided to security agencies by the Federal Government to deal with insecurity in Nigeria. In particular, the Nigeria Security and Civil Defence Corps (NSCDC), the Nigerian Navy, Nigerian Army and the Nigerian Police must be adequately empowered to deal with insecurity.

\section{CONCLUSION}

This article has evaluated the law regarding multi-agency response to oil spill cases in Nigeria. Despite the growing relevance and importance of the multi-agency approach to oil spill management and recognition in relevant Nigerian legislation, its practical implementation in Nigeria remains ineffective. The importance of an effective, efficient and successful multi-agency response to oil spill cases in the country cannot be overemphasized. The multi-agency approach ensures a multidimensional method of dealing with cases of oil spill. Each agency, ministry and company involved in the multi-agency response must know their roles and act according to them in a well-coordinated manner, thus cases of oil spills will be swiftly investigated and dealt with. Also, resources (both human and material) must be used maximally and deployed against any oil spill such that the Nigerian environment (especially the Niger Delta environment) should not suffer incurable damages like in the past. Various stakeholders in the Nigerian oil and gas industry can, and must, work together to ensure that multi-agency response to oil spill cases is a reality and not a mirage.

84 Especially NEMA, NIMASA and DPR. 